\title{
DIAZEPAM AS AN INTRAVENOUS INDUCTION AGENT FOR GENERAL ANAESTHESIA*
}

\author{
ANDRÉ MCCLISH, M.D., F.R.C.P.(c)†
}

Diazepam, $\ddagger$ a new psychotherapeutic agent of the benzodiazepine class, was synthesized by Sternbach and Reeder. ${ }^{1}$ It has an action qualitatively similar to that of chlordiazepoxide to which it is chemically closely related (Fig. 1). It is a colourless crystalline compound, insoluble in water. The injectable solution is yellowish and supplied in $2 \mathrm{ml}$. ampoules containing $10 \mathrm{mg}$; the $\mathrm{pH}$ approximates 6.8 at $20^{\circ} \mathrm{C}$. Mixing this diazepan solution with distilled water, normal saline, or 5 per cent dextrose in water causes visible precipitation and cloudiness. This does not seem to decrease the potency of the drug.

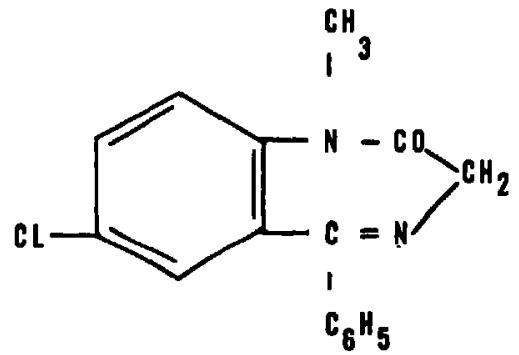

VALIUN (LA III)

(OIAZEPMII)

7-CHLORO-1-METHYL-5-PHENYL-3H-1,4QENZOO|AZEPIN-2(1H)-ONE.

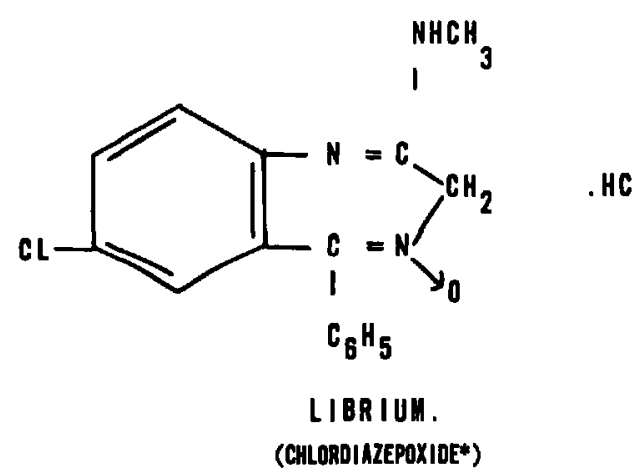

7-CHIORO-2-UETHYLANINO-5-PHEYYL-3H-1, 4-BEHZOOIAZEPINE. 4-OXIOE HYOROCHLORIOE.

FIGURE 1. Structural formulas of diazepam and chlordiazepoxide.

Laboratory and clinical studies have demonstrated tranquillizing, muscle relaxant, and anticonvulsant properties ${ }^{2}$ which exceed those of chlordiazepoxide by more than five times. Diazepam has no analgesic or antiemetic action; it seems to have no effect on the autonomic nervous system and produces little or no depression of respiration or circulation. No extra-pyramidal side effects have been noted with this drug as with the phenothiazines, and it enjoys a very high degree of systemic tolerance.

'Presented at the Annual Meeting of the Canadian Anaesthetists' Society at Banff, June 9, 1966.

†Department of Anaesthesiology and Director of the Research Centre, Institute of Cardiology, Laval Hospital, Quebec, P.Q.

IGeneric and trade names of the drugs mentioned in this report are as follows:

$\begin{array}{llll}\text { amobarbital } & \text { Amytal } & \text { meperidine } & \text { Demerol } \\ \text { chlordiazepoxide } & \text { Librium } & \text { phenobarbital } & \text { Gardenal } \\ \text { diazepam } & \text { Valium } & \text { secobarbital } & \text { Seconal } \\ \text { halothane } & \text { Fluothane } & \text { succinylcholine } & \text { Anectine }\end{array}$

hexylcaine Cyclaine

Can. Anaes. Soc. J., vol. 13, no. 6, November, 1966 
Clinical trials of diazepam have mostly been limited to the treatment of anxiety states and nervous strain in psychiatry. ${ }^{\text {g-6 }}$ In neurology, it has proven useful in treating neuromuscular or musculo-skeletal disorders. ${ }^{7-10}$ In obstetrics and gynecology it has helped to alleviate labour pains and premenstrual tension. ${ }^{11}$ In anaesthesiology, it has been demonstrated to be particularly advantageous as a preanaestheic medication. ${ }^{12-14}$ The patient under diazepam premedication comes to surgery calm, relaxed, and alert, without any evidence of autonomic disturbance or cardiorespiratory depression. Seldom does any patient recall his preparation for induction of anaesthesia even though his lucidity at the time might suggest that the premedicant dosage was insufficient. The amnesia caused by diazepam is a most interesting and useful adjunct in premedication.

Intravenously and at sufficient dosages, diazepam has such remarkable hypnotic effects that certain authors have integrated its use in techniques of anaesthesia without "general anaesthetic" (ataralgesia and neuroleptanalgesia) or to produce narcosis during cardioversion. ${ }^{15-22}$ We were incited to employ diazepam as an intravenous induction agent for inhalation anaesthesia because of the quality of hypnosis produced and the absence of side-effects on respiratory, circulatory, and autonomic nervous systems. It appears to be a good substitute for ultra-shortacting barbiturates, whose ill effects are well known in poor anaesthetic risks, notably cardiac patients.

\section{Materials and Method}

Our clinical study is based on a series of 88 consecutive, unselected patients, admitted to the Quebec Institute of Cardiology, Laval Hospital. These comprise seven cases for cardioversion and 81 cases for various cardiovascular procedures including 30 cases with extra-corporeal circulation (Table I). All patients were induced with diazepam followed by halothane anaesthesia.

The subject group was made up of 38 males and 50 females aged 4 to 74 years (mean $35.4 \pm 16$ years), weighing from 34.5 to $179 \mathrm{lbs}$. (mean $120 \pm 20.6 \mathrm{lbs}$ ). The anaesthesia risk was evaluated under the classification of the American Society of Anaesthesiologists: Class 1, 0 cases; Class 2, 9 cases (10\%); Class 3, 26 cases (30\%); Class 4, 53 cases $(60 \%)^{23}$ (Table II). The average anaesthesia time was 4 hours and 17 minutes, and ranged from 15 minutes to 10 hours and 10 minutes. No fatality occurred up to ten days postoperatively.

\section{A. Premedication}

\section{ANaesthesic Technique}

On the eve of surgery, all patients received orally 5 to $20 \mathrm{mg}$. of diazepam and up to $100 \mathrm{mg}$. of one of the barbiturates: secobarbital, amobarbital, or phenobarbital (Fig. 2). On the morning of the operation, diazepam was administered intramuscularly in doses of 5 to $20 \mathrm{mg}$. (average $17.5 \mathrm{mg}$.) with meperidine (45 to $100 \mathrm{mg}$., average $70 \mathrm{mg}$.). Diazepam alone was given to 21 of 88 patients. Vagolytic drugs were systemically omitted.

\section{B. Induction}

Anaesthesia was induced by rapidly injecting a single intravenous dose of 5 to 
TABLE I

Cardiovascular Procedures

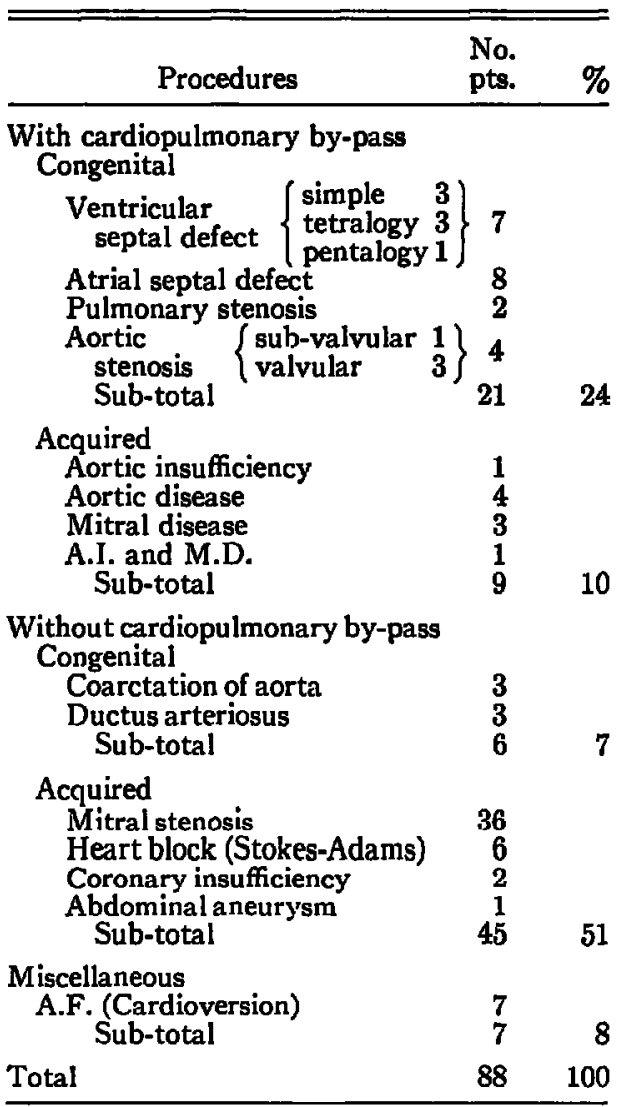

TABLE II

ANAESThETIC Risk*

\begin{tabular}{ccc}
\hline \hline Grade & No. of patients & $\%$ \\
\hline I & 0 & 0 \\
II & 9 & 10 \\
III & 26 & 30 \\
IV & 53 & 60 \\
Total & 88 & 100 \\
\hline
\end{tabular}

American Society of Anesthesiologists.

$20 \mathrm{mg}$. (average $10.7 \pm 3.0 \mathrm{mg}$ ) of diazepam, according to the age, weight, or clinical status of the patient. Following loss of consciousness, induction was continued by mask with a 50:50 mixture of $\mathrm{N}_{2} \mathrm{O}-\mathrm{O}_{2}$ at a flow rate of 6 litres per minute with $\mathrm{CO}_{2}$ absorption, to which an increasing concentration of halothane up to 3 per cent was added over a period of 4 to 5 minutes. Respiration was assisted easily and then controlled manually until central fixation of the eyes, absence of eye reflexes, and a minor fall in blood pressure were attained. 


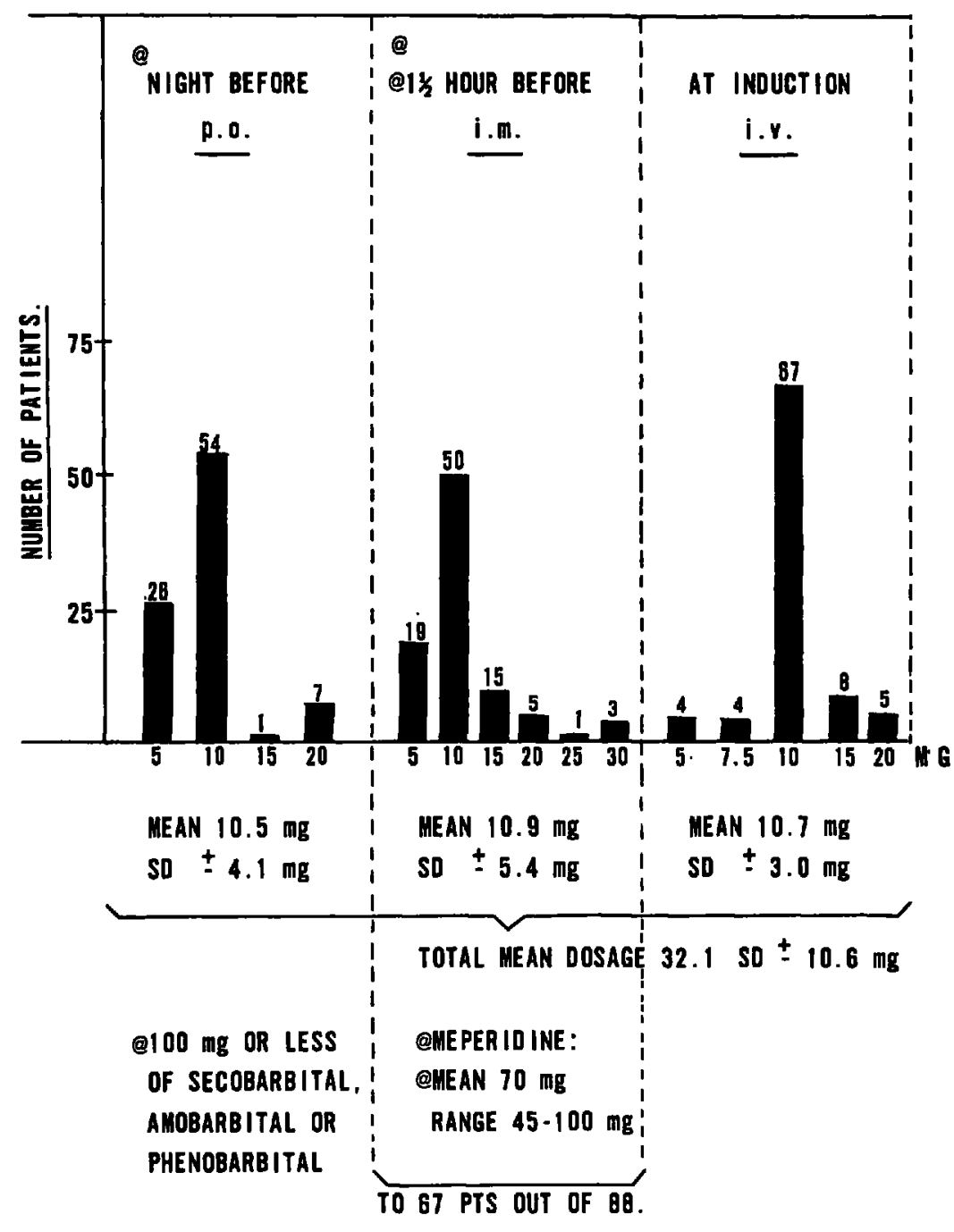

FIGURe 2. Total diazepam dosage in 88 cardiac patients.

The patient was intubated using succinylcholine and/or topical anaesthesia with 5 per cent hexylcaine (Cyclaine). A Heidbrink anaesthesia apparatus with Vernitrol was employed for all cases.

\section{Maintenance}

Light planes of anaesthesia were maintained with the same gaseous mixture, the concentration of halothane being varied from 0.5 to 2 per cent according to surgical needs. Hyperventilation was produced with a Bird Mark IV ventilator from intubation time until closure of the thorax. The Radford ventilatory nomogram was used as a guide.

Except in open heart procedures, no muscle relaxants were needed during maintenance of anaesthesia. The following technique of anaesthesia is performed 
during extra-corporeal circulation: hypothermia $\left(30^{\circ} \mathrm{C}\right.$.) with 0.5 per cent halothane inhalation and either succinylcholine or gallamine in fractional doses. The Sierra or Ruben unidirectional valve has proven very useful in children: it allows mechanical control of respiration and the use of an open circuit method.

\section{Emergence}

Halothane was omitted as soon as the thorax was closed, and narcosis was maintained with the same mixture of $\mathrm{N}_{2} \mathrm{O}-\mathrm{O}_{2}$. The patient usually awakened as the thoracic dressing was being applied. If minute volume, as measured with the Wright anemometer, was satisfactory, the patient was extubated. When transient respiratory difficulties were anticipated (tetralogy of Fallot, aortic or mitral surgery, cardiopathies with pulmonary hypertension, etc.) the endotracheal tube was left in place for 24 to 48 hours and respiration was controlled or assisted with a Bird Mark 8 or 17 respirator. After such a time, a tracheostomy was sometimes deemed necessary.

\section{Evaluation Crtteria}

The time needed to reach unconsciousness was judged from the end of the intravenous injection of diazepam to the time when the patient ceased counting aloud, answering questions, or responding to simple orders. The eyelash reflex, the state of the pupil, the reaction of the airway to assisted or controlled respiration with high concentrations of halothane ( 2.0 to $3.0 \%$ ) were the principal signs used to assess the patient's autonomic functions. The systolic blood pressure, the electrocardiogram, and the respiratory rate were noted before induction and then at two-minute intervals during induction and intubation. Once the patient was intubated, radial blood pressure (sometimes jugular venous pressure), respiratory rate, and electroencephalogram were monitored on a multichannel oscilloscope (Dr-8 Simultrace, Electronics for Medicine). An intra-arterial cannula was installed in $\mathbf{1 7}$ of the $\mathbf{8 8}$ patients before anaesthesia for constant monitoring of blood pressure.

In 7 patients premedicated exclusively with diazepam, arterial blood samples were obtained on the evening before the operation, and the next morning $1 \mathrm{H}$ hours after administration of the drug. Blood gas and $\mathrm{pH}$ concentrations were determined using the Astrup microtechnic and Siggaard-Anderson nomogram. Only objective data have been submitted to appropriate statistical analysis.

\section{RESULTS}

\section{Action on the Nervous System}

Induction of halothane anaesthesia with a single intravenous injection of diazepam (average dose $10.7 \mathrm{mg} .-5$ to $20 \mathrm{mg}$.) proved rapid and smooth in all cases. Unconsciousness supervenes in less than two minutes without any accompanying vagal effects such as coughing, laryngospasm, hiccup, or hypersecretion. The patient experiences a feeling of well-being and relaxation as he gradually fades away into sleep; his speech, at first slurred, rapidly becomes incoherent and then ceases. At the given doses, diazepam produces a light and calm sleep. The patient remains capable of reacting to painful and auditory 
stimuli yet usually recalls nothing of this period. Eye reflexes, including the eyelash reflex, usually persist with the above premedication (diazepam with or without meperidine). Salivary and tracheobronchial secretions are not stimulated even in the absence of vagolytic premedication. In patients who received diazepam only ( 21 cases or $23.8 \%$ ), the pupil remained slightly dilated and the pupillary light reflex persisted. When manually assisted or controlled respirations were commenced with 2 to 3 per cent halothane, reflex phenomena such as coughing and laryngospasm were not elicited.

Diazepam causes slight relaxation of the neck and mandibular muscles. Nevertheless, to obtain a smooth intubation, it remains necessary to employ muscle relaxants and/or local anaesthesia. Diazepam produces sedation, hypnosis, and slight muscle relaxation but no analgesia. Halothane, succinylcholine, and hyperventilation were added to deepen hypnosis and to obtain surgical planes of anaesthesia. However, analgesics must be administered early in the postoperative phase.

When cardioversion is performed, a single intravenous injection of 15 to $20 \mathrm{mg}$. of diazepam is usually sufficient. The patient awakens 20 minutes later without any complication. He seems slightly dazed yet responds well to questions, breathes freely, and shows no sign of circulatory depression. He tends to be euphoric and talkative.

\section{Action on Respiration and Circulation}

In our 88 patients, respiratory rate, systolic blood pressure, and heart rate were noted before and after the intravenous injection of an average dose of $10.7 \mathrm{mg}$. ( 5 to $20 \mathrm{mg}$.) of diazepam. This information is summarized in Table III. According to our statistical analysis, all three of these parameters showed a significant decrease in their average values $(p<0.01)$ after injection of diazepam. This was particularly evident with regard to respiratory rate.

Blood pressure was monitored directly in the last 17 cases, and the same physiologic parameters were studied before and after intravenous injection of diazepam. The average dose was $16.8 \mathrm{mg}$. (10-20 mg.). The results are listed

TABLE III

Effects of Diazepam on Cardiortspiratory Parameters Part I (Indirect Blood Pressure Measurements) (Student $t$-test for matched data)

\begin{tabular}{|c|c|c|c|c|c|}
\hline $\mathrm{N}=\mathbf{8 8}$ & $\begin{array}{c}\text { Before } \\
\text { induction }\end{array}$ & $\begin{array}{c}\text { After } \\
\text { induction }\end{array}$ & $\begin{array}{c}\text { Mean } \\
\text { difference }\end{array}$ & $t$ & $p$ \\
\hline $\begin{array}{l}\text { Respiration (rate/min.) } \\
\text { B.P. Systolic (mm.Hg.) } \\
\text { Pulse (rate/min.) }\end{array}$ & $\begin{array}{r}19.7 \\
130.0 \\
79.7\end{array}$ & $\begin{array}{r}17.9 \\
127.7 \\
76.4\end{array}$ & $\begin{array}{l}1.84 \\
2.26 \\
3.36\end{array}$ & $\begin{array}{l}9.0 \\
2.78 \\
3.3\end{array}$ & $\begin{array}{l}<0.01 \\
<0.01 \\
<0.01\end{array}$ \\
\hline $\begin{array}{l}\text { Diazepam } \\
\quad \text { Induction dose } \\
\text { Premedication dose }\left\{\begin{array}{l}\text { H.S. } \\
\text { A.M. } \\
\text { Total dosage }\end{array}\right.\end{array}$ & $\begin{array}{l}\text { mean } 10.7 \\
\text { mean } 10.5 \\
\text { mean } 10.9 \\
\text { mean } 32.1\end{array}$ & \multicolumn{2}{|c|}{$\begin{array}{l}\text { range } 5-20 \mathrm{mg} . \\
\text { range } 5-20 \mathrm{mg} . \\
\text { range } 5-30 \mathrm{mg} . \\
\text { range } 15-60 \mathrm{mg} .\end{array}$} & & \\
\hline $\begin{array}{l}\text { Meperidine } \\
\text { Premedication dose }\end{array}$ & mean 70.0 & range & 45-100 mg. & & \\
\hline
\end{tabular}


in Table IV. They indicate the absence of any significant change in respiratory rate, systolic and diastolic blood pressure, and heart rate. However a certain degree of respiratory depression was experienced clinically, in terms of depth rather than rate, especially in the aged or in patients whose respiratory load seemed increased. Apnoea never occurred, and respiratory depression was always transitory and rarely accompanied by stertor or snoring.

TABLE IV

Effects of Diazepam on Cardorespiratory Parameters Part II (Direct Blood Pressure Measurements) (Student $t$-test for matched data)

\begin{tabular}{|c|c|c|c|c|c|}
\hline$N=17$ & $\begin{array}{c}\text { Before } \\
\text { induction }\end{array}$ & $\begin{array}{c}\text { After } \\
\text { induction }\end{array}$ & $\begin{array}{c}\text { Mean } \\
\text { difference }\end{array}$ & $t$ & $p$ \\
\hline $\begin{array}{l}\text { Respiration (rate/min.) } \\
\text { B.P. Systolic (mm.Hg.) } \\
\text { B.P. Diastolic (mm.Hg) } \\
\text { Pulse (rate/min.) }\end{array}$ & $\begin{array}{r}17.53 \\
130.70 \\
64.88 \\
87.06\end{array}$ & $\begin{array}{r}15.35 \\
128.29 \\
65.29 \\
88.29\end{array}$ & $\begin{array}{r}2.18 \\
2.41 \\
-0.41 \\
-1.23\end{array}$ & $\begin{array}{r}2.08 \\
1.13 \\
-0.18 \\
-0.69\end{array}$ & $\begin{array}{l}\text { N.S. } \\
\text { N.S. } \\
\text { N.S. } \\
\text { N.S. }\end{array}$ \\
\hline $\begin{array}{l}\text { Diazepam } \\
\quad \text { Induction dose } \\
\text { Premedication dose }\left\{\begin{array}{l}\text { H.S. } \\
\text { A.M. }\end{array}\right. \\
\text { Total dosage }\end{array}$ & $\begin{array}{l}\text { mean } 16.8 \\
\text { mean } 17.8 \\
\text { mean } 16.8 \\
\text { mean } 51.4\end{array}$ & \multicolumn{2}{|c|}{$\begin{array}{l}\text { range } 10-20 \mathrm{mg} . \\
\text { range } 5-20 \mathrm{mg} \text {. } \\
\text { range } 15-20 \mathrm{mg} . \\
\text { range } 40-60 \mathrm{mg} .\end{array}$} & & \\
\hline $\begin{array}{l}\text { Meperidine } \\
\text { Premedication dose }\end{array}$ & mean 10.3 & range & $0-75 \mathrm{mg}$. & & \\
\hline
\end{tabular}

No changes in heart rate or in previously existing electrical anomalies were noted on E.C.G. tracings after diazepam injection. Blood pressure fell 20 to 30 $\mathrm{mm}$. Hg and heart rate decreased by 5 to 10 beats per minute when 2 to 3 per cent halothaine was added to deepen narcosis. These changes usually returned to normal following intubation. An example of the variation in pulse and blood pressure during induction and intubation is illustrated in Figure 3.

No signs of peripheral vasoconstriction were noted with the use of intravenous diazepam. The skin remained dry, warm, and well coloured, and the veins well dilated.

\section{Effects of Diazepam Premedication on Blood Gas Concentrations and $p H$}

Arterial blood gas concentrations and $\mathrm{pH}$ were monitored in 7 patients premedicated exclusively with diazepam, average dose $39.2 \mathrm{mg}$. ( 35 to $45 \mathrm{mg}$.). All 7 were presented with mitral stenosis. Arterial blood samples were obtained on the eve of the operation before the patients received their premedication, and on the next morning $1^{\text {th }}$ hours after their premedication. In both circumstances the patients were breathing room air.

Results are listed in Table V. Statistical analysis reveals that $\mathrm{pH}$ concentration, arterial blood saturation, $\mathrm{P}_{\mathrm{O}_{2}}$, and buffer bases are significantly reduced after administration of diazepam $(p<0.05)$. Considering the cardiorespiratory status of our patients, these results have but very little clinical value and should be considered next to normal.

With diazepam premedication patients arrived at the operating theatre calm, alert, relaxed, and even at times indifferent to the operation they were about to 


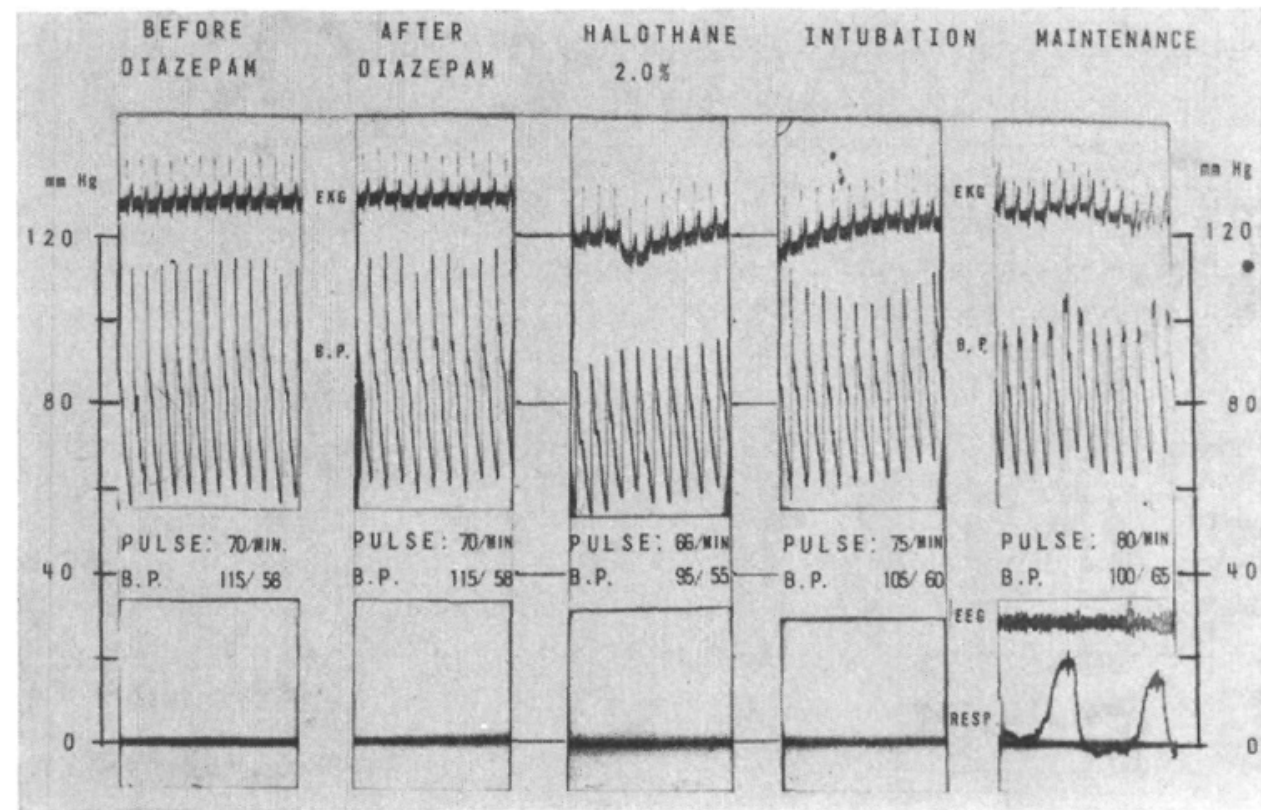

Figure 3. Typical changes in pulse rate and blood pressure after intravenous diazepam and halothane inhalation.

TABLE $V$

Arterial Blood Chemistry before and after Diazeram Premedication (Student $t$-test for matched data)

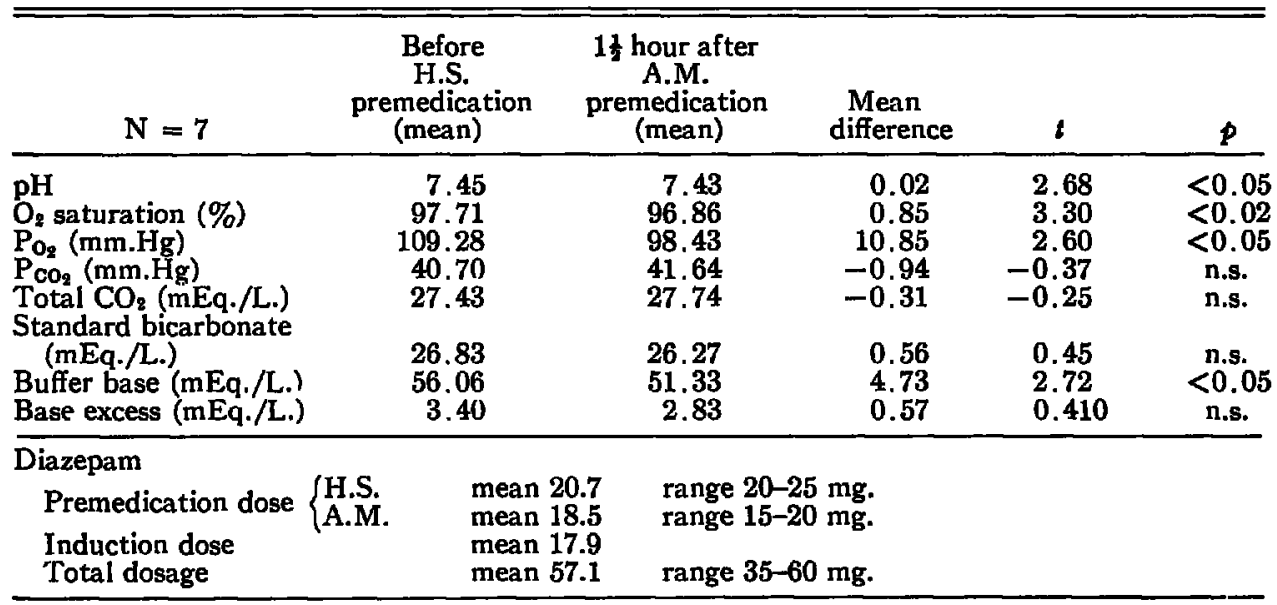

undergo. Furthermore, regardless of their apparent lucidity, they usually recalled nothing of the events preceding anaesthesia.

\section{Side-Effects and Complications}

Out of 88 patients, 20 (22.7\%) complained of a painful burning sensation at the time of intravenous injection of diazepam. Only four of them vaguely remembered having felt pain. There were six cases of venous thrombosis and three 
cases of thrombophlebitis at the site of injection. It must be stated that these veins were also used for blood sampling and administration of drugs and fluids (antibiotics, $\mathrm{KCl}$, cardiac drugs, Rheomacrodex, etc.). No special incident or accident occurred during induction. No allergic reactions or idiosyncrasies were noted following intravenous administration of diazepam.

Emergence, though not instantaneous, was rapid. Narcosis was never prolonged, nor was agitation a problem. Analgesics were usually required the moment the surgical patients awakened.

Most of the patients were subjected to gastric drainage for at least 24 hours postoperatively. Therefore the incidence of nausea and vomiting could not be accurately evaluated. In the seven patients who underwent cardioversion without gastric drainage, there were no cases of nausea or vomiting.

Hepatic and renal function tests were not undertaken to evaluate systemic tolerance to diazepam, since these tests are usually already disturbed in cardiac patients. Blood urea, blood counts, and prothrombin time remained unchanged in all our patients. Jaundice was not observed.

\section{DisCUSSION}

The results of our clinical study clearly demonstrated that diazepam, in a single intravenous dose averaging $10.7 \mathrm{mg}$., is a safe and efficient induction agent for halothane anaesthesia in cardiovascular surgery.

The modern concept of an induction agent is above all a hypnotic that, when injected intravenously at sufficient dosage, produces rapid abolition of consciousness and thereby facilitates the smooth passage to inhalation anaesthesia. It is not expected to possess the properties of a general anaesthetic, which by definition combines in variable proportion hypnosis, analgesia, muscle relaxation, and depression of autonomic reflex activity. Thus two drawbacks of inhalation anaesthesia are eliminated: the anxiety of the mask and the excitation stage. According to this definition both the ultra-short-acting barbiturates and diazepam are good agents for induction of anaesthesia.

During the past 25 years barbiturates have played a major part as induction agents for inhalation anaesthesia because of the rapid and pleasing hypnosis they procure. Although they have anticonvulsant properties, they have no analgesic effect and even act as anti-analgesics. ${ }^{24}$ They induce sleep rapidly but at the same time produce a most undesirable depression of cardiorespiratory function, especially in poor anaesthetic risks. They depress sympathetic transmission more than parasympathetic, an effect which often causes serious accidents during induction (coughing, laryngospasm, hiccup, hypotension, bradycardia, and even cardiac arrest and death ${ }^{25,26}$ ). Premedication must therefore include vagolytic drugs. But the inconveniences of belladona drugs are not to be neglected in cardiac patients: tachycardia, dryness of the mucosae, hypoxaemia and arrhythmias with halothane anaesthesia. ${ }^{27-2 \theta}$ Pharmacologically, these undesirable side-effects limit the indications for ultra-short-acting barbiturates regardless of their excellent qualities as induction agents.

Many non-barbiturate induction agents have undergone trials in anaesthesia 
in the hope that the cardiorespiratory depression and vagal stimulation caused by the barbiturates may be overcome. Among these is Propanidid, a derivative of phenoxyacetic acid (eugenol glycolic acid). Propanidid possesses hypnotic, analgesic, and anticonvulsant properties. So far, however, according to published data, its short action and numerous side-effects have limited its clinical application. ${ }^{30-82}$

Diazepam, on the other hand, due to its hypnotic action and the absence of cardiorespiratory depresssion, is enjoying increasing acceptance (Table VI). It could perhaps be used to advantage in replacing barbiturates as induction agents for general anaesthesia.

TABLE VI

Comparisons between Induction Agents

\begin{tabular}{|c|c|c|c|}
\hline & Diazepam & $\begin{array}{l}\text { Barbiturate } \\
\text { (Thiopental) }\end{array}$ & Propanidid \\
\hline $\begin{array}{l}\text { Premedication } \\
\text { With Belladonna drugs }\end{array}$ & unnecessary & necessary & recommended \\
\hline $\begin{array}{l}\text { Induction } \\
\text { a. dose } \\
\text { b. sleep } \\
\text { c. onset } \\
\text { d. duration }\end{array}$ & $\begin{array}{l}10-20 \mathrm{mg} . \\
\left\{\begin{array}{l}\text { light } \\
\text { quiet }\end{array}\right. \\
<120 \mathrm{sec} . \\
<20 \mathrm{~min} .\end{array}$ & $\begin{array}{l}3.0-3.5 \mathrm{mg} \cdot / \mathrm{kg} .^{*} \\
\text { light } \\
\text { usually quiet } \\
<30 \text { sec. } \\
<25-30 \mathrm{~min} .\end{array}$ & $\begin{array}{l}5.0-6.0 \mathrm{mg} \cdot / \mathrm{kg} \cdot \dagger \\
\text { deep } \\
\text { restless } \\
<20 \mathrm{sec} . \\
<10-15 \mathrm{~min} .\end{array}$ \\
\hline $\begin{array}{l}\text { Effects on: } \\
\text { 1. A.N. system } \\
\text { eye reflexes } \\
\text { protective reflexes } \\
\text { (laryngeal and } \\
\text { tracheal) } \\
\text { secretions (salivary }\end{array}$ & $\begin{array}{l}\text { preserved (eyelash } \\
\text { reflex included) } \\
\text { not stimulated }\end{array}$ & $\begin{array}{l}\text { preserved (conjuntival } \\
\text { reflex excluded) } \\
\text { exaggerated }\end{array}$ & $\begin{array}{l}\text { abolished } \\
\text { abolished }\end{array}$ \\
\hline $\begin{array}{l}\text { and bronchial) } \\
\text { 2. Respiration rate } \\
\text { amplitude }\end{array}$ & $\begin{array}{l}\text { no signif. changes } \\
\text { slightly decreased } \\
\text { no apnoea }\end{array}$ & $\begin{array}{l}\text { decreased (bradypnoea) } \\
\text { decreased with apnoea }\end{array}$ & $\begin{array}{l}\text { increased } \\
\text { (tachypnoea) } \\
\text { decreased with } \\
\text { apnoea }\end{array}$ \\
\hline $\begin{array}{l}\text { 3. Circulation } \\
\text { Pulse } \\
\text { B.P. } \\
\text { E.K.G. }\end{array}$ & $\begin{array}{l}\text { no signif. changes } \\
\text { no signif. changes } \\
\text { no effect }\end{array}$ & $\begin{array}{l}\text { tachycardia } \\
\text { hypotension } \\
\text { no effect }\end{array}$ & $\begin{array}{l}\text { tachycardia } \\
\text { hypotension } \\
\text { no effect }\end{array}$ \\
\hline $\begin{array}{l}\text { Intubation } \\
\text { Without curarization or } \\
\text { local anesthesia* }\end{array}$ & $\begin{array}{l}\text { possible with } \\
\text { hazard }\end{array}$ & possible with hazard & $\begin{array}{l}\text { possible with } \\
\text { hazard }\end{array}$ \\
\hline $\begin{array}{l}\text { Anaesthesia maintenance } \\
\text { Analgesia } \\
\text { Curarization }\end{array}$ & $\begin{array}{l}\text { needed } \\
\text { needed }\end{array}$ & $\begin{array}{l}\text { needed } \\
\text { needed }\end{array}$ & $\begin{array}{l}\text { less needed } \\
\text { needed }\end{array}$ \\
\hline $\begin{array}{l}\text { Postanaesthetic side-effects } \\
\text { a. G.I. naus. and vom. } \\
\text { b. C.V. vein irritation } \\
\text { c. C.N.S. }\end{array}$ & $\begin{array}{l}\text { infrequent } \\
\text { present } \\
\text { euphoria } \\
\text { logorrhea }\end{array}$ & $\begin{array}{l}\text { frequent } \\
\text { absent } \\
\text { prolonged sleep } \\
\text { occasional excitation } \\
\text { headache }\end{array}$ & $\begin{array}{l}\text { more frequent } \\
\text { present } \\
\text { euphoria } \\
\text { headache } \\
\text { muscle rigidity }\end{array}$ \\
\hline Metabolism and excretion & $\begin{array}{l}\text { kidney-faeces } \\
\text { liver }\end{array}$ & liver-muscle & liver \\
\hline
\end{tabular}

*Evans and Gray, General Anaesthesia, 2nd ed. London: Butterworths (1965).

†From Wyant, Wynands: Canad. Anaesth. Soc. J., vol. 12, no. 6, 1965. 


\section{Diazepam as Induction Agent}

\section{Hypnosis}

In addition to its tranquillizing and amnesic effects put to use in premedication, diazepam also has interesting hypnotic properties which can be employed in anaesthesia. These effects are particularly evident when the drug is administered intravenously. H. H. Farb was the first to use the intravenous route as a preparation for narcoanalysis. ${ }^{33}$ Later, intravenous diazepam served as a hypnosisinducing adjunct in anaesthesia "without general anaesthetic" (ataralgesia and neuroleptanalgesia) and as a narcosis-producing preparation for cardioversion..$^{15-22}$ We have used diazepam as an induction agent for halothane anaesthesia in cardiovascular surgery. As almost no analgesia or curarization is achieved, diazepam-induced narcosis must be complemented with analgesics and musclerelaxation agents. This was done with halothane, succinylcholine, and hyperventilation. ${ }^{34-86}$

\section{Muscle Relaxation}

At the average dose of $10.7 \mathrm{mg}$., diazepam has a very mild muscle relaxant effect. According to Stovmer, no potentiation of the action of d-tubocurarine or succinylcholine could be obtained during abdominal surgery with a dose varying from 0.2 to $0.5 \mathrm{mg}$. per $\mathrm{kg}$. of body weight. Furthermore, intubation without reaction was impossible in these conditions. ${ }^{20}$ In Kernohan's experience, diazepam reduces the patient's reaction to synchronized shock during cardioversion. ${ }^{22}$ Although it is our clinical impression that succinylcholine-induced tremors are reduced following administration of diazepam, we do not feel that the degree of muscular contraction caused by the shock during cardioversion is less with diazepam than with barbiturates.

\section{Circulation}

In our series, cardiovascular function was remarkably stable with diazepam. Campan and Stovner report the same results with doses 4 to 8 times those in use in our centre. ${ }^{15-20}$ There is no mention of serious hypotension, tachycardia, or arrhythmias. This is an undisputed advantage of diazepam over barbiturates and Propanidid, especially in poor anaesthetic risks, such as cardiac patients.

\section{Respiration}

No respiratory depression was previously noted during induction with intravenous diazepam. This was verified by many authors. ${ }^{15,10,21}$ Only slight respiratory depression was experienced in our series. Respiratory amplitude seems affected more than rate. The older age group and patients whose respiratory reserve is already taxed seem to be more susceptible than others. Unlike that produced by barbiturates and Propanidid, respiratory depression caused by diazepam is of a moderate and transitory nature and never reaches apnoea. This action seems to be centrally mediated.

Previously disturbed respiratory function is only slightly affected by diazepam premedication. Blood gases and $\mathrm{pH}$ remain almost unaltered, as illustrated in Table V. Moreover, diazepam causes satisfactory preanaesthetic sedation without 
the respiratory depression associated with narcotics. ${ }^{37}$ The amnesia produced is a valuable asset.

\section{Autonomic Functions}

Diazepam does not induce viscero-autonomic imbalance. Unlike barbiturates, it exerts no vagal predominance. Vagolytic drugs were systematically omitted in all our cases. In spite of this, evidence of vagal stimulation during induction was absent. This was equally true for assisted or controlled ventilation with high concentrations of 2 to 3 per cent halothane.

The pain elicited by the intravenous injection of diazepam is of minor consequence. Even though it is frequent (23.8\%), the patient usually recalls nothing of the event. The low $\mathrm{pH}$ and physico-chemical properties of the solvent are most likely responsible for this venous irritation. Campan and Stovner bypass this inconvenience by diluting the drug and giving it in an infusion. ${ }^{15-20}$

Stovner reports a lower incidence of postoperative nausea with diazepam than with barbiturates. ${ }^{20}$ Gastro-intestinal disturbances were absent in the seven patients in our series undergoing cardioversion. In these cases gastric drainage was not employed.

Systemic tolerance to diazepam was high in all of our patients. No aggravation of pre-existing hepatic, renal, or blood disturbances was noted. There were no incidences of jaundice.

\section{SUMmary AND CONCLUSIONS}

Diazepam, a new psycholeptic drug of the benzodiazepine group, is closely related pharmacologically and chemically to chlordiazepoxide. It has proven to be an excellent hypnotic when used intravenously. In 88 patients $(7$ cases of cardioversion, 81 cases of various cardiovascular procedures comprising 31 extracorporeal circulations) induction to halothane anaesthesia was performed using diazepam. A single intravenous dose averaging $10.7 \mathrm{mg}$. induces a rapid, calm and light sleep without producing hypotension, tachycardia, apnoea, or vagal stimulation. Narcosis must be complemented with analgesia and curarization. This was accomplished with halothane, succinylcholine, and hyperventilation. A synergistic action seems to exist between these various agents. Emergence from narcosis is rapid, though not instantaneous. So far no intolerance to this drug has been experienced.

Devoid of undesirable side-effects (such as depression of cardiorespiratory and viscero-autonomic functions) and possessing excellent hypnotic possibilities, intravenous diazepam would seem to be an excellent substitute for barbiturates for the induction of general anaesthesia. This is particularly true for poor anaesthetic risks such as cardiac patients.

\section{Résumé}

Le diazepam est un psycholeptique nouveau du groupe de la benzodiazepine. Il est chimiquement et pharmacologiquement voisin de la chlordiazepoxyde. Par voie veineuse et à dose suffisante, il jouit de propriétés hypnotiques remarquables qui l'ont fait utiliser comme agent d'induction. 
Nous l'avons employé comme substance de départ d'une anesthésie à l'halothane chez 88 patients devant subir une cardioversion ( 7 cas), ou diverses interventions cardiovasculaires ( 81 cas, dont 30 sous circulation extracorporelle).

Le diazepam intraveineux à la dose moyenne et unique de $10.7 \mathrm{mg}$. produit un sommeil rapide, calme et léger, sans provoquer d'hypotension, de tachycardie, d'apnée ou d'hypertonie vagale. La narcose obtenue doit être complétée par une analgésie et une curarisation, ce qui fut réalisé par l'emploi de l'halothane, de la succinylcholine et de l'hyperventilation mécanique. Une synergie d'action peut exister entre ces différents agents. Le réveil est rapide sans être instantané. Aucune intolérance générale n'est survenue jusqu'à présent.

A cause de sa composante hypnotique et de l'absence d'effets indésirables sur la respiration, la circulation et l'équilibre neuro-végétatif, le diazepam intraveineux semble être appelé à remplacer les barbituriques comme agent d'induction en anesthésie générale, notamment chez les mauvais risques anesthésiques, tels les cardiaques.

\section{ACKNOWLEDGMENTS}

We are indebted to Doctor Leon Tetreault, M.Sc.(Pharm.), F.A.C.P., for his contribution to the statistical analysis of our results. Intravenous diazepam was supplied through the courtesy of Hoffmann-LaRoche Company.

\section{ADDENDUM}

Since this report, diazepam has been further used with the same results in 63 additional patients undergoing cardiovascular surgery.

\section{REFERENCES}

1. Sternbach, L. \& ReEder, E. Quinazolines and 1,4-Benzodiazepines IV: Transformations of 7-Chloro-2-methylamino-5-phenyl-3H-1,4-benzodiazepine-4-oxide. J. Org. Chem. 26: 4936 (1961).

2. Randall, L. O.; Heise, G. A.; Schallek, W.; Bagdon, R. E.; Banziger, R.; Bonis, A.; MoE, R. A.; \& Abrams, W. B. Pharmacological and Clinical Studies on Valium, a New Psychotherapeutic Agent of the Benzodiazepine Class. Curr. Ther. Res. 3: 405 (1961).

3. Colland, J. Clinical Experience with Diazepam in Neuroses. J. Neuropsychiat. 3, supp. 1: 157 (1962).

4. Dr Francesco, A. Diazepam, a New Tranquillizer. Amer. J. Psychiat. 119: 989 (1963).

5. Procton, R. C. The Improved Management of Incapacitating Anxiety States. J. Neuropsychiat. 3, supp. 1: 151 (1962).

6. Boitelle, G.; Bortelle-Lentulo, C.; Copengnon, J.; Blotuiras, G.; \& Thomas, J. Indications du R.05-2807 dans les états d'excitation et d'anxiété. Ann. Médico-psychol. 121: 83 (1963).

7. Gastaut, H.; Naquet, R.; Porre, R.; \& Tassinari, C. A. Treatment of Status Epilepticus with Diazepam (Valium). Epilepsia. 6: 167 (1965).

8. Roger, J.; Soulayrol, R.; Lob, H.; \& Tassinaru, C. A. L'Action du diazepain (Valium) dans le traitement des formes non convulsives de l'épilepsie généralisée. Rev. Neurol. 112: 99 (1965).

9. Hendrickse, R. G. \& Sherman, P. M. Therapeutic Trial of Diazepam in Tetanus. Lancet. 1: 737 (1965).

10. Katz, R. A.; Audes, J. H.; \& Recton, M. A New Drug Approach to Muscle Relaxation. J. Neuropsychiat. 3, supp. 1: 91 (1962).

11. HusslenN, H. Emploi du Valium pendant la préparation et pendant l'accouchement. Rev. Med. Psychosomat. 4: (no. spécial) 90 (1962). 
12. Brandt, A. L. \& OAkes, E. D. Preanesthesia Medication: Double-Blind Study of a New Drug, Diazepam. Anesth. Analg. Curr. Res. 44: 125 (1965).

13. Tonnetro, F. J. Diazepam as Preanesthetic Medication: A Double-Blind Study. Anesth. Analg. Curr. Res. 44: 449 (1965).

14. Bozza Marrubini, M. \& Tretola, L. Diazepam as a Preoperative Tranquillizer in NeuroAnaesthesia: A Preliminary Note. Brit. J. Anaesth. 37: 934 (1965).

15. Campan, L. \& Espagno, M. T. Note sur le diazepam en anesthésiologie. Ann. Anesthesiol. Franc. 5: 711 ( 1964).

16. Huguenard, J. \& Margelmon, J. B. Deux Indications particulières du diazepam injectable (induction de la neuroplégie complément de l'analgésie périphérique). Ânn. Anesthesiol. Franc. 5: 731 (1964).

17. Boucquemont, J. G. Essais cliniques du R.05-2807 ou diazepam (Valium) en anesthésiologie. Thèse, Lyon (1964).

18. Rroux, J. Importance de l'analgésie dans l'anesthésie générale: place de l'ataralgésie. Thèse, Montpellier (1960).

19. Blondeau, P. Diazepam et anesthésie générale. Cah. Anesth. 13: 207 ( 1965 ).

20. Stovner, J. \& Endresen, R. Diazepam in Intravenous Anaesthesia. Lancet. 7425: 1298 (1965).

21. Nutrer, D. O. \& Massum, R. A. Diazepam in Cardioversion. New England J. Med. 273: 650 (1965).

22. Kernohan, R. J. Diazepam in Cardioversion. Lancet. 1439: 718 (1966).

23. SAKLAD, M. Grading of Patients for Surgical Procedures. Anesthesiology. 2: 281 (1941).

24. Clutron-Brock, J. Some Pain Threshold Studies with Particular Reference to Thiopentone. Anaesthesia. 15: 71 (1960).

25. DundeE, J. W. Thiopentone and Other Thiobarbiturates. Edinburgh: E. \& S. Livingstone (1956).

26. Edwards, G.; Monton, J. J. V.; Pask, E. A.; \& Wxnm, W. D. Deaths Associated with Anaesthesia. A Report on 1000 cases. Anaesthesia. 11: 194 (1956).

27. Levy, M. L.; Porter, V. P.; \& CoAkley, C. C. Premedication without Vagal Blocking Drugs. Anesth. \& Analg. 43: 33 (1964).

28. Hout, A. T. Premedication with Atropine Should Not Be Routine. Lancet. 2: 983 (1962).

29. Tomlin, P. J.; Conway, C. M.; \& Payne, J. P. Hypoxaemia Due to Atropine. Lancet. I: 14 (1964).

30. Wyant, G. M.; \& Zoerb, D. Propanidid: A New Non-barbiturate Intravenous Anaesthetic. Canad. Anaesth. Soc. J. 12: 567 (1965)

31. Wrnands, J. E. \& Burfoot, M. G. A Clinical Study of Propanidid (FBA 1420). Canad. Anaesth. Soc. J. 12: 587 (1965).

32. Dundee, J. W. \& Crafuke, R. S. J. Clinical Studies of Induction Agents: IX. A Comparative Study of a New Eugenol Derivative, FBA 1420, with G29505 and Standard Barbiturates. Brit. J. Anaesth. 36: 100 (1964).

33. FArB, H. H. Intravenous Diazepam as Pre-interview Medication. Dis. Nerv. Syst. 24, no. 4 (1963).

34. Mcaleavy, J. C.; Way, W. L.; Altstatt, A. H.; Guadagur, J. P.; \& Severinghaus, J. W. The Effect of $\mathrm{P}_{\mathrm{CO}_{2}}$ on the Depth of Anesthesia. Anesthesiology. 2 (1961).

35. Rosinson, J. S. Hyperventilation. In Evans \& Gray, Modern Trends in Anaesthesia, vol. 2, London: Butterworths (1962).

36. Utring, J. H. \& Gray, C. The Initiation of Respiration after Anaesthesia by Passive Pulmonary Hyperventilation. Brit. J. Anaesth. 34: 785 (1962).

37. Prerce, J. A. \& Garofalo, M. L. Preoperative Medication and Its Effect on Blood Gases. J.A.M.A. 5: 194 (1965). 